\title{
BENTHOS OF SPANISH LAKES AND RESERVOIRS
}

\author{
N. Prat, M. Real and M. Rieradevall \\ Dept. Ecologia. Universitat Barcelona, Avda. Diagonal, 645; 08028 Barcelona. Spain
}

Keywords: Benthos, Meiofaunal loop, Benthic typology. Oxygen depletion.

\begin{abstract}
A summary of the results from the study of benthos of lakes and reservoirs in Spain is provided, with a list of the species found to date. Spanish natural lakes are smaller than European lakes; the largest is Lake Sanabria, of glacial origin, which is 3 $\mathrm{Km}$ long and half a kilometer wide. Many are very small and situated in the mountains; more than 200 hundred have been recorded in Spain, but only in Lake Sanabria and Lake Banyoles have the benthos been studied. Lake Sanabria is a cold oligotrophic, monomictic lake with oxygen always present in the deepest zones. Its fauna is similar to that of other central European lakes, with Micropsectra contracta (a chironomid) as the dominant species. Lake Banyoles is a karstic, monomictic and multibasin lake; despite the low primary productivity, due to the abundance of sulphate in the water, the allochthonous inflow of organic matter and the inflow of water from bottom springs, the profundal environment is very stressing for benthic fauna. Very low oxygen concentrations and high sulphide content in the water and sediments dueto meromixis mean that only the larva of the dipteran Chaoborus flavicans was present in one of the 5 basins of the lake. In other basins, when oxygen is available (no meromixis), the fauna is similar to that of the mineralized lakes of the Aegean region and some lakes in central Italia. On the other hand, preliminary data from the Pyrenean lakes and from Sierra Nevada ponds reveal no differences with northern cold lakes.

The largest lakes in Spain are the reservoirs. There are nearly 1000 and data are available on 100 of them, including the largest. In addition to oxygen and sulphide content in the bottom waters, water level fluctuation and high sedimentation rates are disturbance factors that prevented the organization of the community. Allochthonous inputs of organic matter are also an important factor both in the reservoirs and also in the small, oligotrophic lakes like Banyoles and Sanabria. As a result the meiofaunal loop is very important in many of the Spanish water bodies. For this reason the natural lakes and reservoirs of Spain are dominated by Oligochaeta, small crustaceans and the microcarnivore chironomids (such as Procladius, Cladopelma and Microchironomus) that feed on these meoifaunal elements. The phytophagous chironomids, like Chironomus, are only abundant in the shallow areas of mesotrophic and eutrophic reservoirs. This situation makes it difficult to apply the typological system of SAETHER which predicts with some confidence only the benthic communities of Spanish natural lakes above $1500 \mathrm{~m}$ in the Pyrenees or the ponds above $2000 \mathrm{~m}$ in Sierra Nevada mountains. Higher temperatures (which originate a longer stratification period), the presence of sulphate in the waters of the eastern part of Spain and high inputs of sediments and allochthonous organic matter seem to be the factors that originated the differences between the benthic profundal faunas of Spanish lakes and reservoirs and those of the temperate lakes of north and central Europe.
\end{abstract}

\section{INTRODUCTION AND SITES SAMPLED.}

In the last 20 years there has been a considerabl advance in research on benthos in Spanish lakes and reservoirs. Most of the work has been done in connection with different research programmes, especially those devoted to the extensive studies on Spanish reservoirs (MARGALEF et al., 1976). To date. there are data from 131 reservoirs scattered all

Limnetica. 8: 221-229(194)

O Asociación Española de Limnología, Madrid. Spain around Spain (PRAT, 1976, 1978, 1980b, 1980c; REAL \& PRAT, 1991; LIMNOS S.A., 1989; REAL \& PRAT, in press) as well as from lakes Banyoles and Sanabria (RIERADEVALL \& PRAT, 1989, 1991; PRAT \& RIERADEVALL, in press; RIERADEVALL \& REAL, in press, RIERADEVALL et al., in press). These are the two largest natural lakes in Spain. We also have data from the communities of lakes from the Pyrenees (not published) and we 
know the presence in Sierra Nevada lakes and ponds of some species through the adults or pupal exuviae of Chironomidae collected (LAVILLE \& VILCHEZ, 1986). On the other hand the communities of some Pyrenean lakes are well known from the studies in the French Pyrenees (LAVILLE, 1972) and the communities of Spanish Pyrenees should be very similar. The geographical distribution of the sites sampled in Spain is provided in figure 1.

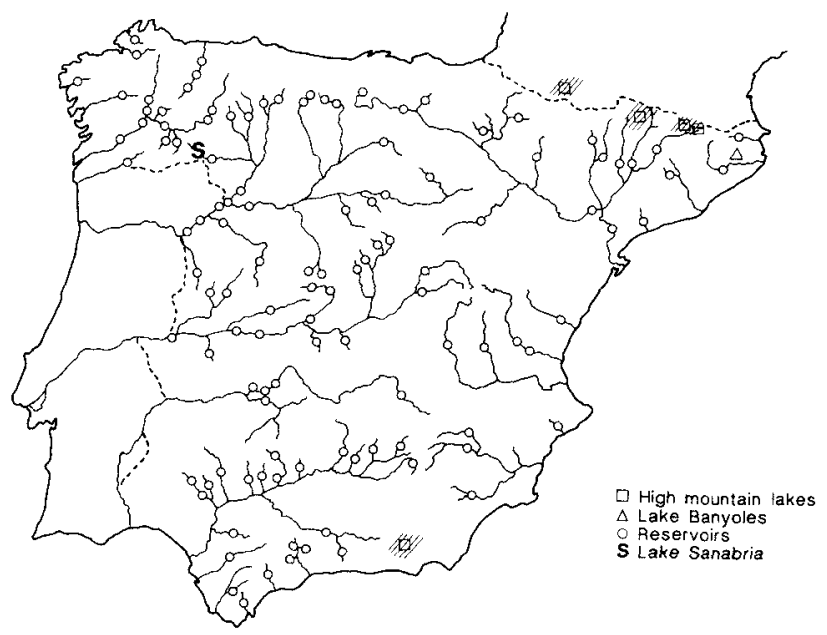

Figure 1. Sites sampled tor benthos in Spain. Open circles are reservoirs, the open triangle Lake Banyoles, the $\mathrm{S}$ is Lake Sanabria and the squares denotes the position of the areas of mountain lakes from which some information exist including those of the lakes investigated in France by LAVILLE (1972).

\section{MACROBENTHIC COMMUNITIES}

We have studied the macrobenthos after sieving the mud taken with Ekman or Van Veen grabs with nets of 150 microns (Banyoles) or 250 microns (other studies). The most complete list for a single lake is that of Banyoles, with a total of 66 species collected in the sublittoral (5-12 m) and the profundal $(20 \mathrm{~m})$ zones in 8 different sampling stations. This list includes some meiobenthic forms (Nematoda, Ostracoda, Copepoda and Cladocera). The list is provided as an appendix to this paper.

Some species frequently found in Spanish lakes and reservoirs are unusual in the species list from central and northern Europe lakes, such as Microchironomus tener and Cladoplema virescens, which have been more frequently and abundantly found in the southern part of Europe (Italy) (BAZZANTI, 1983; SEMINARA \& BAZZANTI, 1988) and in the Aegean lakes (STANKOVIC, 1959) as well as in two lakes in central Europe which have hard waters, i.e. the
Wohlensee and the Balaton. It is also interesting to note that, to date, only 3 species of Chironomus (Ch.plumosus, Ch. bernensis and Ch. nuditarsis) have been found in the lake of Banyoles (RIERADEVALL \& PRAT, 1989) and the Spanish reservoirs (unpublished data) using the chromosomal patterns of collected larvae. Moreover, in lake Banyoles (RIERADEVALL \& REAL, in press) and in some reservoirs (PRAT et al., in press) the worm Potamothrix heuscheri is more frequent and abundant than in other European lakes. The similarity to the Italian lakes is also evident in this case.

\section{THE KEY FACTORS.}

The study of lakes Banyoles and Sanabria and Spanish reservoirs has given us some insights into the importance of several factors in defining the sublittoral and profundal communities

\section{Temperature}

Temperatures of Spanish lakes and reservoirs are higher than those of other European lakes, which influences the species composition. Thus many of the species from artic and alpine lakes are not found in our lakes or reservoris. Only the species composition of the mountain lakes and ponds in Spain over $1500 \mathrm{~m}$ altitude are similar to those of lakes from northern and central Europe. The characteristic chironomid larvae of these lakes such as Heterotrissocladius have been found only in the Pyrenean lakes (unpublished data) and other typical cold-stenotermic species such as Micropsectra bidentata, only in Sierra Nevada mountains (Granada, SE Spain) (LAVILLE \& VILCHEZ, 1986).

Indirect effects of temperature are caused by the duration of thermocline, which can last, in the reservoirs of southern Spain and in Lake Banyoles from the beginning of April until the middle November (RIERADEVALL \& PRAT, 1989). This leads to a depletion of oxygen in the hypolimnion of lakes with lower primary productivity than in central and northern Europe.

\section{Oxygen and sulphide.}

The lack of oxygen in the profundal water has been recognized as the key factor in determining the species composition in the bottom of many lakes. Recent laboratory experiments have shown that physiological adaptations allow some species to live in depleted oxygen environments 
(HEINIS \& CROMMENTJUIN, 1989) and the anoxic metabolism of some Chironomus as also been recorded (FRANK, 1983). The presence of sulphate in waters and sediments can degrade an anoxic profundal environment due to the production of sulphide. While some species can survive in an anoxic environment for some months if sulphide is absent, the presence of this element causes the death of all macroinvertebrates except those able to migrate (such as Chaoborus flavicans). We have two different situations in Spain that demonstrate the importance of these two elements.

In lake Sanabria, a cold, poorly mineralized, monomictic and oligotrophic lake, oxygen is always present in the profunda 1 zone. The community is dominated by Oligochaeta and the chironomid Micropsectra contracta, a typical inhabitant of cold oligotrophic central European lakes such as the Bodensee.

In Lake Banyoles, a temperate, monomictic, mineralized $(1000 \mu \mathrm{S})$ and karstic lake rich in sulphate, the benthic fauna is different in the four different basins investigated depending on the oxygen content of profundal waters (RIERADEVALL \& PRAT, 1991). Due to the morphology of the lake, two basins (III, IV), remain isolated from the main lake (formed by basins I and II) during the stratification period. In basin III permanent meromixis takes place and, as a result, the profundal zone is permanently devoid of oxygen. In basin IV the meromictic process lasts 6 months (table 1). For this reason the fauna in basin III is reduced to the migrant Chaohorus flavicans, and basin IV has a community dominated only by two species of chironomids and one species of Oligochaeta, while the benthic fauna is diverse and abundant in basin I, where anoxia does not occur during the stratification period (RIERADEVALL \& PRAT, 1991). The benthic community is different in each of the basins investigated in Lake Banyoles according to the duration of the anoxia due to meromixis. This rôle of oxygen has been stressed in previous benthic studies (WALSHE, 1950; JONASSON, 1972) and is clearly the key factor in Lake Banyoles and in many Spanish reservoirs, especially in the eastern part, which have sulphate-rich waters. (RIERA \& MORGUI, 1990)

\section{Granulometry of the sediments}

The granulometric composition of the sediments also seems to be important for the macrobenthos. In the sublittoral of both lakes, where the sediment is coarser, the chironomids are more abundant than the Oligochaeta (table 1). The relative abundance of these two groups is strongly

Table 1. Relationship between: depth, months with low oxygen content close to the sediment, mean annual temperature and granulometry of sediment with mean annual density of the most important groups of macrobenthos in lakes of Banyoles and Sanabria. (Data on Banyoles from RIERADEVALL \& PRAT, 1990 and unpublished on Sanabria).

\begin{tabular}{|c|c|c|c|c|c|c|c|c|}
\hline \multirow[b]{2}{*}{ Basin } & \multicolumn{5}{|c|}{ BANYOLES } & \multicolumn{3}{|c|}{ SANABRIA } \\
\hline & III & IV & I & I & I & & & \\
\hline Depth $(\mathrm{m})$ & 20 & 14 & 20 & 12 & 5 & 39 & 13 & $7^{\prime} 5$ \\
\hline Months $\mathrm{O}_{2}<1 \mathrm{ppm}$ & 12 & 6 & 1 & 1 & 0 & 0 & 0 & 0 \\
\hline $\begin{array}{l}\text { Mean annual temperature } 0_{\mathrm{c}} \\
\text { Granulometry } \%\end{array}$ & 12 & 13 & 13.4 & 13.6 & 16.3 & & & \\
\hline $0,2-2 \mathrm{~mm}$ & 0 & 0 & 0 & 0 & 0 & 0 & 0 & 82 \\
\hline $0,05-0,2 \mathrm{~mm}$ & 0 & 0 & 0 & 0 & 6 & 8 & 49 & 13 \\
\hline $0,02-0,05 \mathrm{~mm}$ & 2 & 1 & 1 & 7 & 3 & 25 & 29 & 2 \\
\hline $0,002-0,02 \mathrm{~mm}$ & 71 & 68 & 50 & 64 & 67 & 49 & 18 & 1 \\
\hline$<0,002 \mathrm{~mm}$ & 27 & 31 & 49 & 29 & 24 & 19 & 11 & 1 \\
\hline \multicolumn{9}{|l|}{ Macrobenthos (ind $/ \mathrm{m}^{2}$ ) } \\
\hline Oligochaeta & 0 & 8 & 1303 & 1102 & 850 & 4888 & 1103 & 143 \\
\hline Chironomidae & 0 & 474 & 438 & 2584 & 9178 & 859 & 1070 & 3542 \\
\hline Chaohorus & 465 & 1843 & 239 & 267 & 33 & 0 & 0 & 0 \\
\hline Ephemeroptera & 0 & 0 & 0 & 0 & 8 & 0 & 0 & 50 \\
\hline Others & 0 & 2 & 62 & 241 & 371 & 29 & 2 & 59 \\
\hline
\end{tabular}


affected by this factor and related to depth. Coarse sediments are more frequent in shallower areas and finer sediments in deeper zones. This is one of the reasons that may explain why in some cases, (especially in natural lakes, but not always in reservoirs) the relative abundance of chironomids decreases with depth (RIERADEVALL, 1991).

\section{Water level fluctuations in reservoirs.}

The importance of the previous factors (oxygen, temperature, mineralization and grain size) in the lakes studied is coupled in the Spanish reservoirs to fluctuations in water level. As an example we provide a comparison between species richness and density of the most relevant groups of macrobenthos in three consecutive reservoirs in central Spain (Guadiana river basin) (table 2). 13 stations were sampled in these reservoirs in the main channel, from the tail to the dam of each reservoir (PRAT et al., 1991). The upstream reservoir (CIJARA) has a greater level fluctuation than the other two, the downstream reservoir (ORELLANA) being the least fluctuating. The highest species richness (total number of species found in six bimonthly samples) was found in the tail of the downstream reservoir (station 03 ) at relatively low mean depth $(11,5 \mathrm{~m})$, where oxygen was always present. The lowest species richness was obtained in CIJARA reservoir at the deepest point, where oxygen was always scarce. Some of the stations in the intermediate reservoir (G6-G7), dried up during the year (table 2). Although oxygen was always present in the rest of the year, the species richness and density of macrobenthos was lower in these stations than in those of similar depth in the less-fluctuating reservoir of Orellana (03, table 2). Therefore, water level fluctuation should also be considered as an important factor in community organization of reservoirs (PRAT rt al., 1991).

The food-web structure in relation to the allochthonous inputs.

Finally, we also consider as an important factor, the origin of the available food for animals living in the mud. The ratio between the allochthonous (detritus) and autochthonous (phytoplankton) origin of the food taken by the benthic animals seems to be also a relevant factor. For example, in Lake Banyoles, as the lake is rather small and oligotrophic, the food that reaches the deepest parts is mainly allochthonous detritus, such as leaves, pollen and decaying macrophytes from the littoral, also including some inputs from human origin (manure). In this case detritivores such as oligochaetes, small crustaceans, nematodes and rotifers become abundant and for this reason the meiofaunal loop (as defined in STRAYER, 1990) dominates the food web structure (fig. 2). In these conditions, those species more dependent on the algal production, such as Chironomus, are not frequent. As a consequence, small carnivores like the chironomids Procladius, Microchironomus and Cladopelma as well as the chaoborid Chaoborus flavicans are the dominant species in Lake Banyoles.

Table 2. Mean annual species richness, mean annual density, ratio between mean annual density of Chironomidae and Oligochaeta and dominant chironomid genera in different stations from a three succeaive reservoirs of central Spain (Guadiana river). The mean depth of the six bimonthly samples, the months in which the station has been dry and the number of months with less than 4 and 1 ppm of oxygen in the water close to the sediment of each station is also indicated. The upstream station is $\mathrm{C} 3$ and the downstream is $\mathrm{O} 1 . \mathrm{P}=$ Procladius. $\mathrm{Ch}=$ Chironomus. (Data from PRAT et al., 1991)

\begin{tabular}{|c|c|c|c|c|c|c|c|c|c|c|c|c|c|}
\hline & \multicolumn{3}{|c|}{ ORELLANA } & \multicolumn{7}{|c|}{ GARCIA DE SOLA } & \multicolumn{3}{|c|}{ CIJARA } \\
\hline & $\mathrm{Ol}$ & $\mathrm{O} 2$ & $\mathrm{O} 3$ & G1 & G2 & G3 & G4 & G5 & G6 & G7 & $\mathrm{C} 1$ & $\mathrm{C} 2$ & $\mathrm{C} 3$ \\
\hline Months dry & 0 & 0 & 0 & 0 & 0 & 0 & 0 & 0 & 4 & 5 & 0 & 0 & 0 \\
\hline Mean depth $\mathrm{m}$ & 39 & 31 & 11,5 & 33,8 & 30,1 & 20,1 & 27,5 & 14,5 & 10,2 & 10,2 & 43 & 30 & 23,5 \\
\hline Months $\mathrm{O}_{2}<4 \mathrm{ppm}$ & 4 & 3 & 0 & 3 & 1 & 2 & 2 & 0 & 0 & 1 & 6 & 3 & 1 \\
\hline Months $\mathrm{O}_{2}<1$ ppm & 4 & 4 & 1 & 4 & 3 & 3 & 2 & 1 & 0 & 1 & 8 & 5 & 4 \\
\hline Species richness & 13 & 18 & 26 & 7 & 11 & 9 & 12 & 12 & 11 & 9 & 3 & 7 & 12 \\
\hline Chir./Oligch. & 0,05 & 0,32 & 1,73 & 0,07 & 0,06 & 0,2 & 0,07 & 0,09 & 0,2 & 0,02 & 0,04 & 0,05 & 0,58 \\
\hline Ind $/ \mathrm{m}^{2}$ & 1550 & 2275 & 5975 & 2025 & 1750 & 1875 & 3200 & 3675 & 2500 & 2625 & 250 & 1575 & 1525 \\
\hline Dominant quir & - & $\mathrm{P}$ & $\mathrm{P}-\mathrm{Ch}$, & $\mathrm{P}-\mathrm{Ch}$ & $\mathrm{P}-\mathrm{Ch}$ & $\mathrm{P}-\mathrm{Ch}$ & $\mathrm{P}-\mathrm{Ch}$ & $\mathrm{P}-\mathrm{Ch}$ & $\mathrm{P}$ & $\mathrm{P}$ & & $\mathrm{P}$ & $\mathrm{P}$ \\
\hline
\end{tabular}




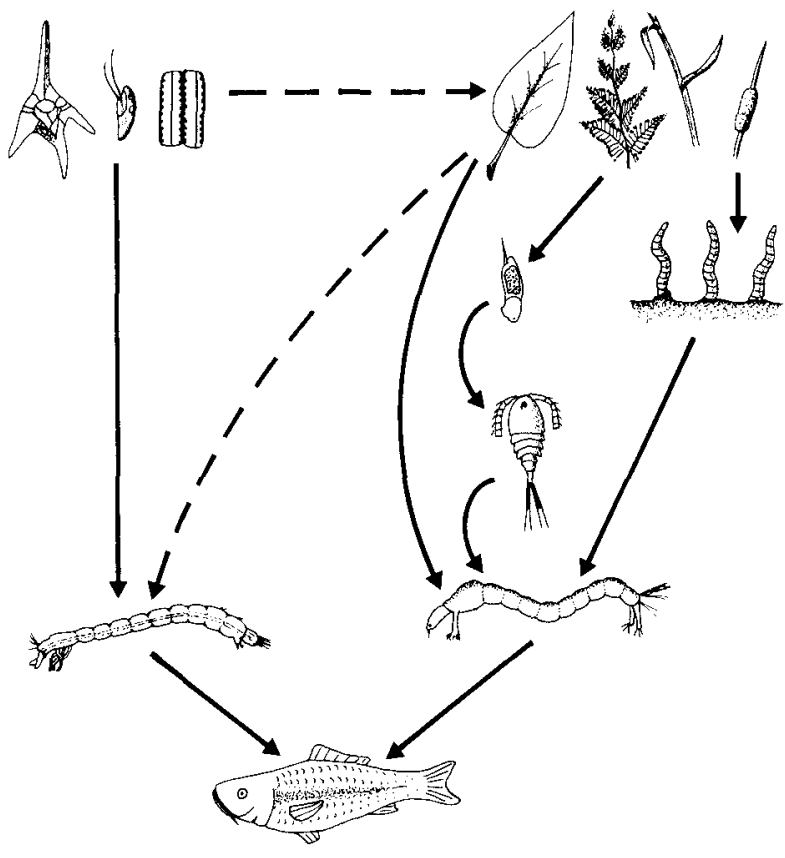

Figure 2. The two routes of nourishment for benthic organisms. In the left the animals are dependent of the fresh phytoplankton produced in the photic zone. In this case the phytophagous macroinvertebrates (such as Chironomus) are favourized. The heterotrophic way (right) is more complex and enhances the presence of many meiofaunal elements (rotifers, crustaceans, nematodes) which fed on bacteria. The abundance of meiofaunal elements is the origin of the abundance of microcarnivorous animals like the chiroiiomid Procladius. The two way are, however. connected and is well know that the phytophagous organism can act as detritivorous or that the phytoplankton can arrive to the bottom in decaying situation and thus enhnacing the meoifaunal loop.

This situation is also typical of many reservoirs especially in forested areas

On the other hand, in reservoirs, water level fluctuation and the rapid accumulation of inorganic sedirnent due to erosion enhance the presence of mobile forms like Procladius, which is the most abundant chironomid species in Spanish reservoirs (PRAT, 1980; REAL com. pers.).

In eutrophic reservoirs, especially shallower reservoirs with more stable water levels, the profundal zone receives greater quantities of fresher phytoplankton material. In this case the phytophagous chironomids (Chironomus, Sticto(hironomus) are more abundant. Nevertheless, the animals of the meiofaunal loop can also be frequent and abundant in eutrophic deeper reservoirs (REAL \& PRAT, in press), where these material reachcs the bottom in a more advancing state of decay. As a hypothesis that is currently being tested, with some preliminary results published (REAL \& PRAT, in press), we suggest that the ratio between Procla- dius and Chironomus should provide us with information relevant to the food web structure.

\section{TYPOLOGY.}

Benthos has always been considered as a good indicator of the trophic degree of lakes. Since THJENEMANN and later BRUNDJN (1958), different indicator species have been used. The typology most frequently used today is that of SAETHER (1979) with 15 different types of lakes which can be related to the mean annual chlorophyll or phosphorous content of the water divided by the mean depth of the lake.

We have tried, unsuccesefully, apply this System to Spanish lakes and reservoirs (fig. 3). Lake Banyoles and sorne oligotrophic and mesotrophic reservoirs have commu-
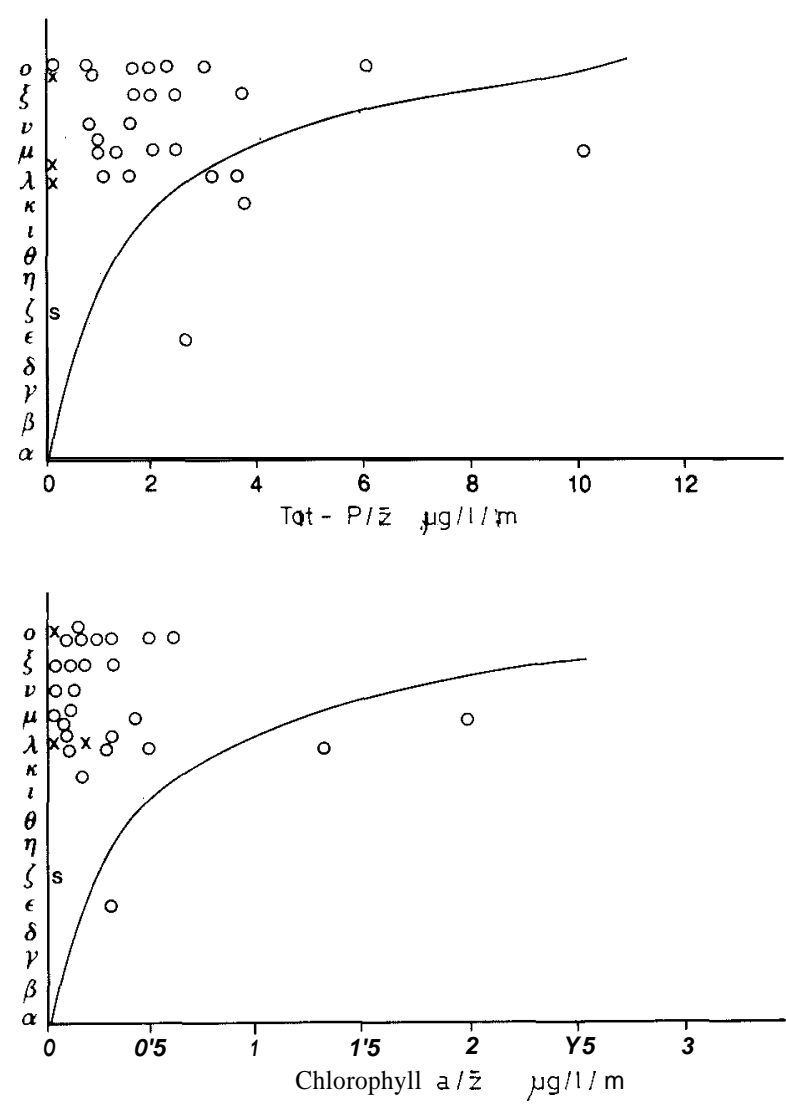

Figure 3. Position of the Lake Banyolen (crosses). Lake Sanabria (S) and sorne reservoirs (open circles) in the typological system creüted by SAETHER. No relationship is observed between the communities present in Spanish lakes and reservoirs and the eutrophication of the waters 
nities normally considered as typical of eutrophic lakes. The different basins of Banyoles are classed in different parts of the system and nearly all of the reservoirs considered (20, all in the Duero basin) are classified in the last 5 classes of the SAETHER's system (fig. 3). Only the lakes of the Pyrenees and the Sierra Morena ponds fit well into the first. ultraoligotrophic classes. We can consider Lake Sanabria and only one reservoir in the to the mountains in the 5 intermediate levels

As a conclusion, the typology used for northern European and American lakes is not very useful for the southern part of Europe; it can be applied only to natural lakes over 1500 $\mathrm{m}$ in the Pyrenees and ponds over $2000 \mathrm{~m}$ in Sierra Nevada. As many of our reservoirs are below these altitudes. the thermal characteristics prevent the presence of many indicator species. The benthic community of the profundal areas of our reservoirs are largely determined by the oxygen content, the water level fluctuations and the allochthonous inputs of organic matter. As the oxygen content close to the bottom in Mediterranean and subtropical climates is not related to eutrophy to such an extent as in northern lakes (Mc CULLOGH \& JACKSON, 1985), our communities do not fit the SAETHER's typology, which has been developed for cold temperate lakes. We have also to consider the origin of the food consumed by the benthic animals, especially in the oligotrophic lakes and reservoirs, and the importance of watershed uses and erosion as well as water level fluctuations in the reservoirs The communities developed under such conditions cannot be related to eutrophication and for this reason the typological system of SAETHER is not appropriate.

\section{CONCLUSIONS.}

The main conclusion of our work is that in Spain, and in general in the southern European lakes, at altitudes lower than $1500 \mathrm{~m}$, owing to the thermal conditions (long thermocline period) coupled in many cases to high sulphate content in the waters, oxygen depletion close to the bottom is found at lower eutrophication levels than in northern and central European lakes. The comparison between Banyoles and Sanabria lakes (both oligotrophic, at similar latitudes, but at different altitudes and with -very different thermal regime and water mineralization) is clear in this respect. In addition, the abundance of allochthonous inputs enhances the meiofaunal loop, which could explain the abundance of small microcarnivores in our lakes and reservoirs (like the chironomid Procladius). The presence of this chironomid in reservoirs is also enhanced by the high sedimentation rate. The phytophagous chironomids, like Chironomus, are only abundant in shallower areas of eutrophic reservoirs especially in winter or spring, being absent from the profundal areas during summer especially in sulphate-rich waters. This reduces the community to the most resistent species and makes it difficult to use the indicator system adopted for other lakes.

\section{ACKNOWLEDGMENTS.}

This work has been made possible by different CAYCIT contracts and due to the collaboration of many people who assisted us in sampling and sorting. Special thanks are due to Enrique Martínez-Ansemil, Josefina Sanz, Isabel Muñoz and Carles Ibáñez. LIMNOS S.A. have provided us with an unpublished report used in our work.

\section{REFERENCES.}

BAZZANTI, M., 1983. Composition and diversity of the profundal rnacrozoobenthic community in the polluted lake Nemi (Central Italy). 1979-80. Acta Oecol. oecol. appl., 4(3): 211-220.

BRUNDIN, L., 1958. The bottom faunistical lake type system and its application to the southern hemisphere. Moreoever a theory of glacial as a factor of productivity in lakes and oceans. Verh. internat. verein. Limnol., 13: 288-297.

FRANK , C.. 1983. Ecology, production and anaerobic metabolism of Chironomus plumosus L. in a shallow lake II Anaerobic metabolism. Arch. Hydrobiol., 96: 354-362.

HEINIS, F. \& T. CROMMENTUIJN, . 1989. The natural habitat of the deposit feeding chironomid larvae Stictochironomus histrio (Fab) and Chironomus anthracinus Zett. in relation to their responses to changing oxygen concentrations. Acta Biol. Debrec. Oecol. Hung., 3: 141-146.

JONASSON, P.M.. 1972. Ecology and production of the profundal benthos. Oikos, suppl., 14: 1-148.

LAVILLE, H., 1972. Recherches sur les chironomides (Dipt) des lacs du massif de Néouvielle (Hautes-Pyrénées). Première partie: Systématique. Ecologie, Phénologie. Ann. Limnol. 7: 173-332.

LAVILLE. H. \& A. VILCHEZ. 1986. Les Chironomidés (Diptera) de quelques "lagunas" de haute altitude de la Sierra Nevada (Granada. Espagne). Annls. Limnol. 22(1): 53-63. 
LIMNOS S.A., 1989. Estudio diagnóstico de la calidad de las aguas embalsadas de la comunidad de Castilla y León: Determinación y previsión de impactos, propuesta de corrección y red de vigilancia. 3 tomos.

MARTINEZ-ANSEMIL, E. \& N. PRAT, 1984. Oligochaeta from profundal zones of Spanish reservoirs. Hydrobiologia, 115:223-230.

MARGALEF et. al.1976. Limnologia da los embalses españoles. Public. Minist. Obras Públicas. n”. 123.

Mc CULlOUGH. J.D. \& D. W. JACKSON,1985. Composition and productivity of the benthic macroinvertebrate community of a subtropical reservoir. Int. Revue ges. Hydrobiol. 70: 221-233.

PRAT, N.. 1976. Fauna bentónica de los embalses españoles. Resúmenes II Asamblea Nacional de Geodesia y Geofísica. págs. 2041-2054.

1978. Benthic typology of Spanish reservoirs. Verh. internut. verein. Limnol., 20: 1647-1651.

1979a. Quironómidos de los embalses españoles (1). Graellsia. XXXIII: 37-96.

1979b. Fauna marginal de los embalses españoles. Misc. Zoologica, 5: 149-160.

1980a. Quironómidos de los embalses españoles (II). Graellsia, XXXIV: 59-119.

1980b. Bentos de los embalses españoles. Oecol. aquat., 4: 3-43.

$1980 \mathrm{c}$. Benthic population dynamics in artificial samplers in an Spanish reservoir. IN: Chironomidae: Ecology. Systematics and Physiology (D.A. Murray ed.). págs, 239-246. Pergamon Press. Oxford and New York.

PRAT, N. \& V. DAROCA, 1983. Eutrophication processes of Spanish reservoirs as revealed by biological records in profundal sediments. Hydrobiologia, 103: 153-158.

PRAT, N., J. SANZ, \& E. MARTINEZ-ANSEMIL, 1991. El bentos litoral y profundo de una cadena de tres embalses españoles del rio Guadiana. Limnetica. , 7 : 133-152

PRAT, N. \& M. RIERADEVALL, in press. Life cycle and production of Cladopelma virescens (Mg.) (Dipt. Chironomidae) in lake of Banyoles (NE Spain). Hydrobiol. Bull.
REAL, M. \& N. PRAT, 1991. Changes in the benthos of five Spanish reservoirs in the last 15 years. Verh. internat. verein. Limnol., 24: 1377-1381.

in press. Factors influencing the profundal macrozoobenthos of Spanish reservoirs. Hydrobiol. Bull.

REAL, M.; F. SABATER, \& J.A. MORGUI,. in press. Significant physiographic disturbances in the Ebro basin (NE Spain) reflected by Oligochaeta size spectra. Hydrobiologia.

RIERA, J.L. \& J.A. MORGUI, 1990. Limnología regional de los embalses españoles. Mundo Científico, 104: 720-726.

RIERADEVALL, M. 1991. Ecologia i producció del hentos del llac de Banyoles. Tesi Doctoral. Universitat de Barcelona. 223 págs.

RIERADEVALL, M. \& N. PRAT, 1989. Chironomidae from profundal samples of Banyoles lake. Acta Biol. Debr. Oecol. Hung., 3: 267-274.

1991. Benthic fauna of Banyoles Iake. Verh. internat. verein. Limnol., 24: 1020-1023.

RIERADEVALL, M. \& M. REAL, in press. Sublittoral and profundal fauna from Lake Banyoles (Catalonia, NE Spain). Hydrobiologia.

RIERADEVALL, M.; C. IBAÑEZ; I. MUÑOZ; M. REAL \& N. PRAT, in press. Grupos de macroinvertebrados del bentos del lago de Sanabria y su relación con la granulometria del sedimento. Actas VI Congreso Español de Limnologia.

SAETHER, O.A. 1979. Chironomid communities as water quality indicators. Holarct. Ecol., 2: 65-74.

STRAYER, D.L. 1991. Perspectives on the size structure of lacustrine zoobenthos, its causes and its consequences. Journal N. Am. Bentol. Soc., 10 (2):210-221.

SEMINARA, M.\& M. BAZZANTI,. 1988. Trophic level assessment of profundal sediments of the artificial lake Campotosto (Central Italy), using midge larval community (Dipt. Chir.). Hydrobiol. Bull., 22(2): 183-193.

WALSHE, B. M. 1950. The function of haemoglobin in Chirońomus plumosus under natural conditions. J. exp. Biol., 27: 73-95. 


\section{APENDIX.}

List of species found in the profunda1 and sublittoral areas from Spanish lakes and reservoirs. $B=$ Banyoles, $S=S a n a b r i a$, $\mathrm{R}=$ Reservoirs.

\section{NEMATODA}

Daptonema dubium, $B$

Dorylaimus stagnalis, $B, R$

Limnomermis bostrychodes, $R$

Tobrilus sp. (T. gracilis), $B, R$

\section{OLIGOCHAETA}

Dero digitata, $B, R$,

Aulodrilus pluriseta, $R$

Aulodrilus pigueti, $B, R$

Branchiura sowerbyi, $B, R$.

Limnodrilus claparedeianus, $B, R$

L. hoffmeisteri, $B, R$,

Limnodrilus profundicola, $R$

L. udekemianus, $R$

Potamothrix bavaricus, $B, R$

P. hammoniensis. $B, R$,

$P$. heuscheri, $B . R$

Tubifex tubifex, $R$

Psammoryctides barbatus, $B, R$

$R$. buchholzi, $R$,

$B$. appendiculata

\section{BIVALVIA}

Pisidium milium, $B$

Pisidium nitidum. $B$

\section{CRUSTACEA}

\section{MACROTRICIDAE}

Ilyocryptus sordidus, $B, R$,

\section{CHIDORIDAE}

Alona affinis, $\mathrm{B}$

Alona quadrangularis, $B$

Scapholeberis sp., B,

COPEPODA

Cyclops sp., B, R,

Diacyclops bicuspidatus, $B$

Eucyclops serrulatus, $B$

OSTRACODA

Candona neglecta, B

Cyclocypris ovum. $B$
Ironus ignavus, $R$

Ironus elegans, $B$

Ironus cf. tenuicaudatus, $B$

Mermithis, $B$

\section{Paranais frici, $R$}

Nais pardalis, $R$

Nais communis, $R$

Nais barbata, $R$.

Nais variabilis, $R$.

Nais pseudobtusa, $R$.

Ophionais serpentina, $R$

Pr.menoni, $R$,

Uncinais uncinata, $R$

Spirosperma ferox, $R, S$

Haber pyrenaicus, $S$

Embolocepahlus velutinus, $S$

Bothrionerum vejdowskyanum, $R$

Fridericia sp., $R$.

Pisidium obtusale, $B$

Pisidium subtruncatum, $B$

Leydigia acanthocercoides, $B$

Leydigia leydigii, $B$

Macrocyclops albidus, $B$

Paracyclops fimbriatus, $B$

Cyprideis torosa, $B$

Ilyocypris bradyi, $B$ 
Cypria lacustris, $B$

Darwinula stevensoni

GAMMARIDAE

Echinogammarus pungens, B

\section{HYDRACARINA}

Arrenurus sinuator, $\mathrm{B}$

Neumania deltoides , $B$

INSECTA

EPHEMEROPTERA

Ephemera glaucops, B

DIPTERA

CHAOBORIDAE

Chaoborus flavicans, $B, R$.

CHIRONOMIDAE

Procladius cf. choreus, $B, R$

Tanypus punctipennis, $B, R$,

Ablabesmyia sp., $B, R$

Cricotopus (I.) sylvestris, $B, R$,

Cricotopus gr. bicinctus, $B, R$,

Cricotopus gr. festivellus, $B$

Chironomus plumosus, $B . R$,

$C h$. nuditarsis, $B, R$,

Ch. bernensis, $B, R$,

Cladopelma virescens, $B, R$,

Cryptochironomus sp., $B, R$,

Cryptotendipes sp., $B$, ,

Harnischia sp., $B, R$,

Microchironomus tener, $B, R$

Microtendipes sp., $B, R$,

Paracladopelmasp. $B$,

Paratendipes sp., $B$

Polypedilum spp., $B, R$,

Stictochironomus maculipennis, $B, R$,

Cladotanytarsus atridorsum, $B, R$,

Micropsectra sp., $R, S$

Stempellina $s p ., B, R$,

Tanytarsus gr. lestagei, $B$.
Ilyocypris gibba, $B$

Isocypcis beauchampi

Neumania imitata, $B$

Unionicola crassipes, $B$

$P$. parvulus, $R$
A. longistyla, $R$
Prodiamesa olivacea, $R$
Parakiefferiella batophila, $R$
Ch. halophilus, $R$.

H. fuscimana, $R$

M. pedellus, $R$
S. histrio, $R$
C. mancus, $R$
M. contracta, $R$
S. bausei, $R$
T. batophilus, $R$ 